\title{
Codzienność i świat przeżywany: gdzie jest miejsce dla znaczeń religijnych?
}

\begin{abstract}
The paper analyses categories of every-day reality and of a life-world, reaching also for a related notion of intersubjectivity. Whereas all of them have phenomenological background, only the category of every-day reality has made a career in sociology, breaking off the connection with its philosophical roots. Its phenomenological interpretations are recurred to in the article, together with showing its relation to Lebenswelt. The main concern is the extent to which it is possible to find religious meanings in every-day life in contemporary societies of the broadly-understood West. A degree to which it is allowed to bring meanings deriving from other spheres into the scope of every-day reality, as well as a concrete symbolic domain to be privileged, are historically and culturally changeable. Secularization that affects a society in an institutional dimension and its common sense, makes religious interpretations being less and less intersubjectively supported and loosing their status of being taken for granted. This situation encourages further secularization of individual life-worlds, and at persons who still identify themselves as religious strengthens the separation of religious province from the other domains of meanings and ways of experiencing the world. There is also a number of people who, despite the decline of
\end{abstract}

1 Anna Małgorzata Królikowska, Instytut Socjologii, Wydział Humanistyczny, Uniwersytet Szczeciński, Polska, anna_krolikowska@wp.pl. 
presence of religious elements in widely shared common sense, perceive their lives through the prism of religious interpretations, and try to shape their own every-day life in this perspective. A remedy to the evanescence of confirmation in every-day communication are smaller communities clustered around shared meanings, as well as a stronger emphasising an experiential aspect. In the circumstances of the multitude of potentially internalizeable interpretative systems, differentiation of world-views and attitudes to the religious stuff, and lesser presence of religious meanings beyond religious institutions, the life-world category, meant as an individual representation of reality and a frame for experiences, can become an adequate tool of studying.

\section{Keywords:}

life-world, every-day reality, phenomenology, religious meanings, secularization

\section{WSTĘP}

Artykuł ten powraca do bliskich relacji pomiędzy socjologią a filozofią, niekiedy ganionych (Mokrzycki, 1992), lecz trudnych do uniknięcia, gdy sięga się po kategorie pojęciowe przekraczające granice dzielące te dyscypliny. Tu pojęciami tymi są codzienność i świat przeżywany. Oba mają rodowód w filozofii. Pierwsze z nich zadomowiło się na dobre w socjologii, gdzie w ciągu ostatnich dekad utworzył się silny nurt socjologii codzienności. W drugim przypadku, pomimo że Zdzisław Krasnodębski pisał na początku lat 90. o świecie przeżywanym jako o ,jednym z najmodniejszych pojęć” filozofii i socjologii (1991, s. 39), to z dzisiejszej perspektywy widać, że, jeśli chodzi o socjologię, było w tych słowach sporo przesady.

Kategorie codzienności i świata przeżywanego zostaną rozpatrzone w kontekście współczesnych zjawisk dotyczących religii i religijności. Jednym z podstawowych przejawów sekularyzacji jest dążenie poszczególnych instytucji do oparcia swego funkcjonowania na własnych racjonalnościach i systemach znaczeń, odrębnych od religijnych interpretacji (Luhmann, 1998; Casanova, 2006). Chociaż Peter Berger (1998) przekonywał, że sekularyzacja struktur nie znajduje przełożenia na poziom indywidualnej świadomości, trudno zgodzić się z tezą o braku takiej zależności, podobnie jednak jak z odwrotną do niej tezą o bezwyjątkowym zeświecczeniu prywatnych obrazów świata. Ważną strukturą pośredniczącą na drodze do indywidualnej świadomości jest kultura życia codziennego. Współczesna 
potoczność w społeczeństwach o zaawansowanych procesach sekularyzacyjnych, które bywają dodatkowo wzmocnione odgórnym sekularyzmem (Calhoun, Juergensmeyer, VanAntwerpen, 2011), wyzbywa się religijnych odniesień, i jako taka nie stwarza jednostkom okazji do kontaktu z sakralnymi znaczeniami. W społeczeństwach o wyższych wskaźnikach religijności, lecz ulegających sekularyzacji zmiany te zachodzą między innymi właśnie poprzez laicyzowanie się kultury i praktyk codzienności. Mimo to, procesy sekularyzacyjne nie tylko nie mają charakteru linearnego (Mariański, 2006; Casanova, 2006), lecz także nie w pełni dają się tłumaczyć zróżnicowaniami strukturalnymi, środowiskowymi czy przestrzennymi (por. Lash, 2009). Gdy sekularyzacji towarzyszą pewne tendencje o odwrotnym wektorze, istnieje szczególny kontekst dla pytania, czy codzienność jest (wciąż?) miejscem, w którym obecne są elementy religijne? Różnorodność postaw wobec religii i wielość prywatnych ontologii skłania ku sięgnięciu po kategorię świata przeżywanego, która może okazać się szczególnie przydatna w warunkach kulturowego zróżnicowania. Częsta sytuacja rozbieżności pomiędzy indywidualnym światopoglądem a interpretacjami dominującymi w społecznym otoczeniu przywołuje też na powrót fenomenologiczne i bezpośrednio związane z wspomnianymi kategoriami zagadnienie intersubiektywności.

\section{CODZIENNOŚĆ JAKO POJĘCIE O FENOMENOLOGICZNYM RODOWODZIE}

Pojęcia codzienności i świata przeżywanego wywodzą się z fenomenologii. Podczas gdy kategoria świata przeżywanego wciąż zachowuje tę relację, związek pomiędzy kategorią codzienności a jej fenomenologicznym źródłem w naukach społecznych praktycznie został zerwany. Dorobek paradygmatu podpadającego pod hasło „socjologia codzienności” wciąż się powiększa (Sztompka, Bogunia-Borowska, 2008). Jednak przenikanie się w codzienności elementów kultury, historii i biologiczności istnienia oraz istotność aspektu świadomościowego sprawiają, że trudno jest zamknąć jej badanie w jednej dziedzinie. W tym obszarze zainteresowania przejawia się raczej zjawisko nazwane przez Clifforda Geertza (2005) „zmąceniem gatunków”.

Codzienność jest doświadczana jako oczywista i oswojona, jest obszarem intensywnej intersubiektywności jako podstawy komunikacji (Schütz, Luckmann, 1973; Schütz 1982), oraz głównie rutynowej aktywności. W literaturze fenomenologicznej charakteryzowana jest przede wszystkim przez właściwy jej styl poznawczy (Cicourel, 1989). Codzienność cechować ma nastawienie naturalne, na właściwości 
którego składają się realizm epistemologiczny, „naiwność”, czyli bezdyskusyjna gotowość przyjmowania danych rzeczywistości, tworzenie typizacji i idealizacji. Alfred Schütz za jej główną cechę uznał „,natarczywość pragmatycznego motywu” (Schütz, Luckmann, 1973, s. 28-29). Według niego i kontynuatorów, świat życia codziennego jest strukturowany przez praktyczne zainteresowania podmiotu i zrozumiałe, intersubiektywnie podtrzymywane reguły. Założenie, że świat życia codziennego stanowi główne miejsce przebywania świadomości i zasadniczy obszar aktywności (Berger, Luckmann, 1983) oznacza uznanie dominacji aktywistycznego nastawienia i kontekstowego zaabsorbowania w całości doświadczania życia i świata. Współczesny styl życia sprzyja rozszerzaniu spektrum doświadczeń podpadających pod codzienność (Golka, 2009). Do pragmatycznego nastawienia dołączyć należy aktywność o charakterze rozrywki, wycieczki w świat wirtualny, postmodernistyczne wzory konsumpcji. O ile codzienność można rozumieć jako zwykły, powtarzalny i zrutynizowany tryb doświadczeń i praktyk wraz z mieszczącą je czasoprzestrzenią każdorazowego „tu i teraz”, to bezpośrednio z nią związane pojęcie potoczności można potraktować jako odsyłające do elementów kulturowych, czyli gotowych już zestawów interpretacyjnych użytecznych w radzeniu sobie w codzienności w wymiarze poznawczym i komunikacyjnym. Codzienność uznaje się za najważniejszy obszar komunikacji. Peter Berger i Thomas Luckmann idą w tej tezie tak daleko, iż twierdzą, że w ogóle język powstaje w „rzeczywistości zdominowanej przez motyw pragmatyczny” (1983, s. 74).

\section{KATEGORIA ŚWIATA PRZEŻYWANEGO}

Świat przeżywany może być rozumiany obiektywizująco lub w perspektywie subiektywnej. Na pierwszy z tych sposobów Lebenswelt jest interpretowany przez Jürgena Habermasa (2000; 2003), dla którego jest on przede wszystkim przestrzenią porozumienia i działania komunikacyjnego, a także przez Jana Patočkę (1987), skupionego na jego wymiarze aksjologicznym. Od Edmunda Husserla wywodzi się traktowanie świata przeżywanego jako doświadczanego z perspektywy podmiotu (Husserl, 1989; Coenen, 1989). Niekiedy oba ujęcia na poziomie teoretycznej analizy mieszają się. W pewien sposób podobnie odbywa się to też w perspektywie uczestnika życia społecznego. Subiektywny odbiór świata oscyluje między doświadczaniem jego obiektywności, mocnej jego oczywistością, a świadomością przyglądania mu się z własnego „punktu zero”. W każdym przypadku cechą świata jest bycie znaczącym (Węgrzecki, 1999). Świat sugeruje ontologię, życie - trwanie, kategorie egzystencjalne, przeżycia i działania podejmowane w dostępnej, 
znaczącej przestrzeni. W pojęciu świata przeżywanego składowe te występują nierozdzielnie, bowiem chodzi o zaznaczenie „przenikania tych dwóch różnych realności” (Rolewski, 1999, s. 94). Odnajdywana jest bezpośrednia analogia do „bycia-w-świecie” jako kluczowego ujęcia sytuacji egzystencjalnej człowieka przez Heideggera (1994; Rolewski, 1999; Habermas, 2000). Świat przeżywany „stanowi wszechogarniający horyzont sensu wszystkich zamkniętych sfer sensu” (Grathoff, 1989, s. 443); to „horyzont naszej konkretnej egzystencji” (Coenen, 1989, s. 269). Sławomir Mandes także u A. Schütza odnajduje uznanie świata przeżywanego za „fundament wszystkich form aktywności” (2012, s. 18), powstający „dopiero poprzez symboliczne zintegrowanie poszczególnych rzeczywistości oraz dużych transcendencji” (ibidem, s. 80).

Niemiecki termin Lebenswelt jest tłumaczony zarówno jako „świat życia” i jako „świat przeżywany”. Uznanie, że różnica między nimi ma znaczenie, pozwala skorzystać z dokonanego przez Wilhelma Diltheya (2004) rozróżnienia pomiędzy życiem a przeżywaniem. Tak jak życie wykracza poza jednostkową świadomość, tak świat życia nasuwa raczej myśl o zhumanizowanej przez znaczenia, usensownionej przestrzeni bytowania, doświadczania i działania. I tak jak według Diltheya przeżywanie jest nieustannym podmiotowym doświadczaniem przesuwania się pasma teraźniejszości, tak określenie „świat przeżywany’ sugeruje scentralizowanie doświadczania rzeczywistości w podmiocie. Akcentowanie przeżywania nie oznacza odrzucenia roli działania, gdyż pozostają one w bezpośrednim związku (Tischner, 1993; Luhmann, 1998). Świat przeżywany zogniskowany w podmiocie, relatywny do jego wiedzy i doświadczeń, a więc taki, jaki „obowiązuje dla danych osób” (Husserl, 1989, s. 56), ma walor niepowtarzalności, ale i od początku jest naznaczony kulturowo (Schütz, Luckmann, 1973). Husserl rozróżniał w nim aprioryczną, istotową strukturę naiwnego ujmowania świata i nadbudowaną nad nią warstwę zmienną dziejowo, kształtowaną kulturowo, społecznie i biograficznie (Rolewski, 1999). Twórca XX-wiecznej fenomenologii nastawienie naturalne przypisywał światu przeżywanemu, a dopiero potem Schütz związał je z codziennością.

\section{PRZEMIANY CODZIENNOŚĆI I ŚWIATÓW PRZEŻYWANYCH}

Pojęcia codzienności i świata przeżywanego mogą być wykorzystywane w naukach społecznych ze względu na swą społeczno-historyczną zmienność i kontekstowe uwarunkowania. Pomostami łączącymi ego z zewnętrzną rzeczywistością znaczeń kulturowych są socjalizacja i potrzeba uzyskiwania społecznego potwierdzenia, współkonstytuującego obrazy i interpretacje rzeczywistości. Światy jednostkowe 
nie są autarkiczne, muszą być zasilane z zewnątrz, umacniać się w porozumieniu, na co szczególnie zwrócili uwagę etnometodolodzy (Cicourel, 1984). Nawet u solipsystycznego Husserla komentatorzy znajdują zainteresowanie problemem intersubiektywności i wspólnoty (Tischner, 1993; Duranti, 2010). Niekoniecznie musi to być codzienne doświadczanie tego, co Schütz określał mianem przekładalności perspektyw (1982), a co odwołuje się do całkowitego „zapomnienia o inności” (Lachowska, 1987, s. 172). Przy współczesnym zróżnicowaniu społeczeństw nie tylko nie jest tak, że przekładalność perspektyw powszechnie się sprawdza², ale też potocznym doświadczeniem ludzi staje się świadomość, że „w wielu sprawach się nie zrozumiemy”.

Przy współobecności w przestrzeni społeczno-kulturowej systemów znaczeń trudnych do wzajemnego uzgadniania, a nawet translacji, większe jest zróżnicowanie światów przeżywanych jako korelatów indywidualnej świadomości. Tak rozumiana heterogeniczność kulturowa kształtuje też codzienność. Ograniczeniu ulega to, co w codziennym komunikowaniu tak przez nadawcę, jak i przez odbiorcę bez wahania ujęte będzie jako samo przez się zrozumiałe. Podzielany powszechnie, a tym samym stanowiący wspólny mianownik zakres kultury potoczności zawęża się i skupiając się wokół pewnych neutralnych obszarów tematycznych, omija inne. Z drugiej strony, pomimo tez, że współczesny człowiek jest znacznie bardziej niż kiedyś wyswobodzony z kolektywistycznych przywiązań i że cechuje go gotowość do refleksji (Lash, 2009), trudno przyjąć, by indywidualizacja tak bardzo wyemancypowała jednostkę, że stała się ona obojętna na doświadczanie braku tego, co dla naturalnego nastawienia podstawowe: intersubiektywnego potwierdzania, i że posiadanie społecznego zaplecza dla własnych wersji interpretacyjnych stało się zbędne. Przyjąć też należy, że człowiek nie może żyć bez pewnego zakresu przekonań, na co dzień nieobjętych powątpiewaniem (Zimmerman, Pollner, 1989). Szansę na operowanie założeniem, że inny widzi rzeczywistość tak jak ja, wzmacniającym zaufanie do własnej wizji rzeczywistości, dają małe „wspólnoty sensu”. Ulf Hannerz uważa, że w złożonych społeczeństwach, w których trudno o dużą skalę wspólnoty kulturowej, odnawia się ona „na niższym poziomie organizacyjnym” (2006, s. 289). Gdy wspólnoty znaczeniowe zapewniające poczucie swojskości (Patočka, 1987) cechuje stosunkowo znaczny stopień zamkniętości, można mówić o enklawach światopoglądowych (por. Machaj, Gołdyka, 2007; 2009). Często jednak więzi wspierające indywidualne światy przeżywane są utrzymywane przez

2 Dorota Lachowska zauważa, że teza o przekładalności perspektyw nie sprawdza się, gdyż Inny musiałby być „pojęty tylko jako analogon ego” (1987, s. 172). Bernhard Waldenfels (1989) zauważa, że Schütz, skupiony na rozumieniu, usunął z pola uwagi „wzajemne niezrozumienie”. 
niebezpośrednie relacje, co obrazuje, że - mówiąc słowami Bergera i Luckmanna „wspólnota sensu nie zakłada wspólnoty życia” (1995, za: Mandes, 2012, s. 182).

Warto też zauważyć potrzebę dynamicznego spojrzenia na indywidualne światy przeżywane. Różnice między wiedzą kulturowo nabytą w pierwotnej socjalizacji a „aprobowaną społecznie” dziś wytwarzają pola możliwych napięć. Interpretacja Alfreda Schütza (co może wydać się dziwne z perspektywy jego biografii) nie przewidywała sytuacji kulturowego naporu, konfrontacji nowego ze starym. W intensywnie zmieniającym się społeczeństwie ta różnica może być istotnym czynnikiem oddziałującym na świadomość. Indywidualne światy przeżywane, choć stoją wobec sprzecznych wpływów i konfrontacji perspektyw, przejawiają pewien stopień wewnętrznej koherencji, zaś życie codzienne to pod pewnym względem dążenie do odnalezienia swojskości i takie manewrowanie pomiędzy wielością interpretacji, by unieść cało własne „łańcuchy oczywistości”.

\section{CODZIENNOŚĆ I ŚWIATY PRZEŻYWANE A ZNACZENIA RELIGIJNE}

W pytaniach pojawiających się w ramach socjologii przedmiotem zainteresowania jest to, czy codzienność jako obszar zwykłego funkcjonowania „zwyczajnych” członków społeczeństwa zawiera w sobie elementy religijne, czy religia bierze udział w konstruowaniu „podstawowych parametrów codzienności” (Borowik, 1990, s. 11). Odpowiedź na pytanie o obecność religii w codzienności jest utrudniona przez niejednakowy zakres wyznaczany dla tej kategorii przez różnych badaczy. Rozbieżności dotyczą takich kwestii jak to, czy jest w codzienności miejsce dla aksjologii (James, 1957; 1958), czy też funkcjonują w niej jedynie pragmatyczne motywy (Schütz, Luckmann, 1973); czy podmiot w nastawieniu właściwym codzienności jest świadomy własnej skończoności (Natanson, 1982; Berger, Luckmann, 1983), czy przeciwnie, „życie w teraźniejszości nie zna śmierci” (Wittgenstein, 1995, s. 62; Heidegger, 1994); czy codzienność mieści w sobie wymiar egzystencjalny (Brach-Czaina, 1999; Jackson, 2008), czy jest on do odnalezienia tylko poza światem powszedniości (Heidegger, 1994; Tischner, 1993), wreszcie, jak kwalifikować święta: czy według klucza indywidualnego sposobu doświadczania, czy arbitralnie, według zobiektywizowanych kryteriów (Borowik, 1990). Po drugie, czynnikiem różnicującym odpowiedzi na ten temat jest sposób definiowania religii: czy chodzi o religię pojmowaną substancjalnie, czy funkcjonalnie, węziej - instytucjonalnie, czy szerzej - pozainstytucjonalnie.

Jeśli dla Husserla liczyły się dwa sposoby patrzenia na rzeczywistość: naukowy i naturalny, to postawa religijna mieściła się w nastawieniu naturalnym świata 
przeżywanego (Krasnodębski, 1991). U Schütza zaś wiązała się z przeniesieniem się świadomości do odrębnego od codzienności, specyficznego i ograniczonego obszaru znaczeń (1999). W interpretacji Bergera i Luckmanna, kontynuatorów Schützowskiej koncepcji wychodzącej z konsekwentnego operowania perspektywą doświadczającego podmiotu, zinstytucjonalizowana, oparta na formułach i wyrażana w rytuałach religijność należy do sfery potoczności, a dopiero abstrahujące od nich subiektywne przeżycie religijne wykracza poza codzienność (1983; Berger, 1990). Według nich, codzienność dominuje nad innymi, zawsze ograniczonymi sferami znaczeń, pełniącymi dla świadomości jedynie rolę „miejsc wypadowych” (Berger, Luckmann, 1983). Zgoła inaczej relacje międzydziedzinowe mają się w fenomenologii religii czy fenomenologizujacej antropologii kulturowej. W zestawieniu perspektywy religijnej z potoczną, naukową i estetyczną, Clifford Geertz odnajduje tę pierwszą jako najszerszą i obejmującą potoczność (1992). Takiej hierarchii od ludzi religijnych wymaga też definicja religii, mówiąca o „przyporządkowaniu co do znaczenia spraw rzeczywistości empirycznej rzeczywistości pozaempirycznej” (Piwowarski, 1974, s. 217). Ten typ ujęcia subiektywnej wizji świata nie respektuje tezy o ostrym rozgraniczeniu między dziedzinami znaczeń. Zakłada, wbrew tezom o niepodważalnie nadrzędnym statusie codzienności, że jeden z obszarów znaczeniowych „stanowi jak gdyby pryzmat, w którym załamują się pozostałe, filtr określający percepcję obiektów leżących poza obszarem pierwszoplanowym” (Manterys, 1997, s. 32). Dość zaskakujące, że także Schütz przyznaje, iż codzienność może być naznaczona przez symbole pochodzące z innych dziedzin (1999).

Przynajmniej częściowe wyjaśnienie sprzeczności poglądów na możliwość obecności w codzienności znaczeń religijnych przynosi wyjście poza rozważanie specyfiki ahistorycznych podmiotowych „nastrojeń” i posłużenie się filtrem kultury. Treści wysycające potoczność, choć zachowujące sporą inercję, podlegają historycznym zmianom. Pozwala to mówić o właściwej danym czasom i miejscu kulturze codzienności, która w różnym stopniu przyzwala na udział w niej znaczeń religijnych. Istotne jest więc rozróżnienie pomiędzy nastawieniem podmiotu a samymi znaczeniami. Standardy nastawienia właściwego codzienności tworzą barierę przeciwdziałającą bezpośredniemu wtargnięciu doświadczenia religijnego (Caillois, 1995), podobnie jak odrzucane są próby włączania do codziennej komunikacji standardów naukowej ścisłości (Garfinkel, 1989). Jeśli potoczność ma skłonność do separowania się od nietypowych dla niej sposobów narracji, to udział treści symbolicznych pochodzących z innych zakresów sensów jest regulowany kulturowo, podobnie jak to, która dziedzina ma prawo infiltrować potoczność swymi znaczeniami. Prymat sakralnych interpretacji w społeczeństwach opartych 
na tradycji nie oznacza, że rzeczywistość religijna jest codziennym podstawowym miejscem pobytu świadomości, ale raczej, że znaczenia wywodzące się ze sfery religii infiltrują potoczność, przyjmując właściwy codzienności modus, przybierając status oczywistości czy niewymagających refleksji „uniwersalnych projekcji” (Luckmann, 1989). Uzwyczajnione i „unormalnione” interpretacje religijne mogą istnieć w potoczności i codzienności, uzyskując tam intersubiektywne wzmocnienia, lub zostać z niej wyrugowane jako nieuprawnione i dziwaczne. W kulturze Zachodu, a szczególnie Europy, funkcjonowanie wybranych elementów religijnego przekazu instytucjonalnego, często zwłaszcza w niższych warstwach społecznych pospołu z magicznymi jako składnika potocznej, taken for granted wiedzy zbiorowej należy już w znacznej mierze do przeszłości. W porównaniu z elementami rzeczywistości dostępnymi „naoczności”, znaczeniom religijnym szczególnie trudno jest utrzymać status oczywistości bez intersubiektywnego podtrzymywania. Dziś potoczność jest w dużej mierze przeniknięta treściami i interpretacjami pochodzącymi z obszaru nauki. Współczesne doświadczenia i praktyki życia codziennego Niklas Luhmann określa jako „idealizująco-technicyzujące” (1998, s. 99), a Habermas uważa za zdeformowane jednostronną racjonalizacją (2000, s. 162-163). Poza modernistyczną racjonalnością, wzrosła też rola postmodernistycznej ironii i dystansu. Taka kultura codzienności nie sprzyja komplementarnej współobecności w niej znaczeń religijnych. W języku dnia codziennego naszego społeczeństwa odnaleźć można jeszcze wiele elementów uprzedniego naznaczenia codzienności religią, choć na ogół zwroty te nie są już faktycznie religijnie znaczące. Badacz żyjący w społeczeństwie bardziej zsekularyzowanym niż społeczeństwo polskie stwierdza, że dziś codzienne sytuacje nie stwarzają żadnych okazji do rozmów na tematy religijne, ani też nie dopuszcza tego konwencja społeczna (Luhmann, 1998). Uznanie wiary za sprawę prywatną ma „znaczący wpływ na udostępnienie i zapewnienie religii innym” (Luhmann, 1998, s. 230). W warunkach sekularyzacji ważne jest też to, czy w kulturze nie przeważają elementy z religią zdecydowanie niezgodne i ją podważające, z jakim nasileniem krytykowana jest religia instytucjonalna, jej przedstawiciele, jej relacje ze sferą publiczną czy wpływ na kulturę. Różne są też charakterystyki i dynamiki odnoszenia się do udziału treści religijnych w obszarze intersubiektywności w społeczeństwach monowyznaniowych i spluralizowanych religijnie, a także w zależności od lokalnej tradycji przyzwalania lub zakazywania obecności religii w przestrzeni publicznej. W wielu społeczeństwach bycie religijnym nie jest już powszechnie obowiązującą normą, a nawet normą staje się bezreligijność ${ }^{3}$. Charles Taylor zauważa, że poszerzają się kręgi społeczne,

${ }^{3}$ Wśród jedenastu najbardziej zsekularyzowanych społeczeństw świata jest siedem państw eu- 
w których postrzeganie rzeczywistości w perspektywie znaczeń religijnych jest traktowane jako nienormalność ${ }^{4}$ (2007).

Jedna z głównych tez sekularyzacji traktuje o aksjonormatywnym i ideowym rozchodzeniu się podsystemów społecznych, ich uniezależnianiu się od wpływu religii (Luhmann, 1998; Casanova, 2006). Zachowanie religijnej perspektywy, wbrew twierdzeniom Bergera (1998), nie jest łatwe wobec powiększającego się braku komplementarności pomiędzy świeckimi strukturami znaczeniowymi a religijną. Opisana przez Schütza strukturyzacja nastawień świadomości doznaje wzmocnienia wynikającego z rosnących rozbieżności między sektorowo obowiązującymi znaczeniami. Sporo osób utrzymujących jakiś rodzaj więzi z Kościołem, nawet podtrzymywanej cotygodniowym udziałem w zbiorowych praktykach, komplementarnie do dyferencjacji i emancypowania się racjonalności struktur społecznych, pozostawia dla religijnej perspektywy niewielką „przegródkę”, separując doświadczenia życia codziennego od niemal jakiegokolwiek jej wpływu. Wciąż deklarując się jako osoby religijne, uruchamiają ten rodzaj znaczeń jedynie w kontekście instytucjonalnym lub w wyjątkowych sytuacjach osobistych, poza nimi nie poszukując przełożenia religijnych sensów na inne sfery życia i nie angażując ich w przebiegu codziennych zaabsorbowań.

W społeczeństwach poddanych sekularnej dyferencjacji segmentów instytucjonalnych wciąż jednak są ludzie podpadający pod interpretację Geertza. W ich przypadku perspektywa religijna oddziałuje na osobiste „struktury sensu” i „struktury istotności”, znacząco współkonstruując sposób doświadczania. Zasięg wyjaśnień, jakie oferuje religia, i zasięg oddziaływań sfery sakralnej widzą oni jako nie dające się zamknąć w jednej dziedzinie, lecz jako kontekst całości. W tej perspektywie sacrum jawi się jako ogarniające rozmaite modi doświadczenia, jako Bergerowski Kosmos i Nomos (1990). Sposobu religijności, w której znaczenia religijne oddziałują integrująco na cały świat przeżywany, nie należy traktować jako reliktu czasów dawnej hegemonii znaczeń religijnych, lecz raczej jako potwierdzenie tezy o nielinearnym charakterze zmian religijności. Jednak uczestniczenie w dzielonej

ropejskich. Szwajcaria, Francja, Islandia, Stany Zjednoczone, Kanada i Austria w latach 2005-2012 odnotowały co najmniej dziesięcioprocentowy spadek wskaźników religijności (w tym Szwajcaria i Francja o 21 p.p.). Interesujące są zmiany w społeczeństwie amerykańskim, ukształtowanym według wzoru modernizacji niesprzecznej z religijnością. Trzeba też dostrzec kraje cechujące się wzrostem deklaracji religijności, jak Macedonia, Rumunia, Mołdawia, Serbia (wzrost ten nie przekracza jednak 5 p.p.; Global Index Of Religiosity And Atheism. WIN-Gallup International 2012. Pobrane z: http:// www.wingia.com/web/files/news/14/file/14.pdf) czy Ukraina (Gatskova, 2014).

4 Potoczność ma znaczący udział w wyznaczaniu kryteriów normalności (Garfinkel 1989; Geertz, 2005). 
z innymi codzienności pozbawionej spopularyzowanych elementów religijnych, a także coraz bardziej przesycanej potocznymi treściami, które z religią nie dają się uzgadniać, utrudnia znajdowanie społecznego potwierdzenia dla religijnych ontologii i nomosów światów przeżywanych. Tych zaś, którzy starają się wnosić religię w swoją codzienność, wystawia na poważną próbę. Według Charlesa Taylora, zmiana warunków wyznawania wiary polegająca na funkcjonowaniu w odmiennym światopoglądowo otoczeniu to jeden z najistotniejszych przejawów „ery sekularnej” (2007). Mimo silnej obecności dyskursu o sprywatyzowanej i zindywidualizowanej religijności, zdaniem Luhmanna, nie przestaje obowiązywać twierdzenie, że społeczna komunikacja, stanowiąc warunek wytwarzania i odtwarzania się znaczącego przeżywania i działania, pełni ważną rolę w podtrzymywaniu przekonania o realności sfery sacrum (1998). Osoby religijne na sposób instytucjonalny komunikację tę znajdują w przestrzeni Kościoła, lecz jej specjalistyczny i tradycyjny styl może okazać się zbyt hermetyczny i słabo przekładalny na codzienne sensy. Intersubiektywne potwierdzanie sensowności utrzymywania religijnego „pryzmatu” dla świata przeżywanego może być dodatkowo odnajdywane w relacjach na innych płaszczyznach, także stricte społecznych. Przy zmianie kulturowej w kierunku sekularyzacji życia codziennego rośnie rola wzmocnień, jakie osoby religijne mogą uzyskać w relacjach towarzyskich w niewielkich enklawach sensu tworzonych przez wspólnoty religijne czy kręgi przyparafialne ${ }^{5}$. Dodatkowo, przy wycofywaniu religii z kultury popularnej ${ }^{6}$, zarówno będącej emanacją potoczności, jak i ją kształtującej, instytucje religijne dążą do wzmocnienia aspektu przeżywaniowego. Ta zmiana może być szczególnie widoczna w polskim katolicyzmie, który ze względu na uwarunkowania historyczne długo był realizacją wzoru Kościoła ludu. Sekularyzacja, postępująca pluralizacja kulturowa, słabszy międzygeneracyjny przekaz i wystawienie jednostki na naciski konformizujące w kierunku bezreligijności są czynnikami skłaniającymi instytucje religijne do uruchamiania strategii zwiększających interioryzację religijności. Dążenie do uzyskania efektu uwewnętrznienia i w tym sensie zindywidualizowania religijności widoczne jest w treściach homilii, w których mówi się o odwadze świadczenia o własnej wierze wbrew niechęci otoczenia, w mobilizowaniu do stałego utrzymywania relacji z Bogiem i przyjmowania komunii, w głoszeniu związku między religijną

${ }^{5}$ W 1998 r. było w Polsce 251 rodzajów organizacji laikatu, w 2008 już 2104. Najwięcej ich powstało w miastach. Źródło: Społeczny potencjał parafii. Działalność przyparafialnych organizacji Kościoła katolickiego w Polsce w 2012 r. GUS, ISKK (2014).

6 Przykładem jest zmiana treści kartek świątecznych na mniej religijne, brak informacji o świętach religijnych w kalendarzu, sekularyzowanie się św. Mikołaja, powszechne świętowanie Halloween itp. 
duchowością a innymi sferami funkcjonowania, w organizowaniu nabożeństw uzdrowienia. Instytucjonalne ramy doświadczenia ograniczają indywidualizację potencjalnie wiążącą się z większą subiektywizacją doświadczenia, dostarczając tematów, wzorów, interpretacji i regularności (Schelsky, 1998), a zbiorowy rytuał może stanowić znaczący kontekst dla osobistego doświadczenia (McGuire, 2008). Niektórzy przywódcy religijni stają się animatorami przeżyć poprzez wykraczające poza rytuał oddziaływanie charyzmatycznej osobowości, co w ostatnich latach bodajże najdobitniej pokazuje przykład spotkań z o. Johnem Bashoborą.

\section{ZAKOŃCZENIE}

W artykule analizowane były częściowo zbieżne i mające wspólny rodowód pojęcia codzienności i świata przeżywanego. Analiza ukierunkowana była pytaniem, czy i w jaki sposób w obszarach przez nie konotowanych we współczesnych zsekularyzowanych i sekularyzujących się społeczeństwach funkcjonują znaczenia religijne. Sekularyzacja i wzrost stopnia złożoności społeczeństwa zmniejszają prawdopodobieństwo napotkania religijnych sensów w codzienności, które tym samym przestają być samo przez się zrozumiałymi oczywistościami. Zmienia się powszechnie podzielana kultura potoczności oraz reguły i treści codziennej komunikacji. W obliczu malejącego udziału interpretacji religijnych w języku i praktykach codzienności oraz zróżnicowania postaw wobec przekazu religijnego zyskuje na znaczeniu kategoria świata przeżywanego, rozumiana jako zsubiektywizowany obraz rzeczywistości i rama indywidualnych doświadczeń. Wzajemne oddalanie się na poziomie makrospołecznym treści i układów normatywnych poszczególnych instytucji społecznych sprzyja takiej topografii subiektywnych światów przeżywanych, w której znaczenia religijne pozostają zamknięte w wąskim, odseparowanym obszarze, nie przenikając do sfery spraw codziennych. W wielu przypadkach subiektywne światy przeżywane pozbawione są całkowicie elementów religijnych, jednak u części osób sfera religijna nadal przenika granice dziedzin znaczeń i doświadczeń. Choć treści religijne, także te poprzez kulturę i historię związane z danym społeczeństwem, a nawet nadal umocowane w jego instytucjach, nie mogą mieć statusu potocznej oczywistości, zapewnianego kiedyś przez intersubiektywną jednozgodność, pewnym sposobem na odnalezienie potwierdzania znaczeń w przestrzeni codzienności są mniejsze zakresowo wspólnoty ogniskujące się wokół podzielanych sensów. Wobec stałego wystawienia na niebezpieczeństwo zrywania „łańcuchów oczywistości” rośnie też rola doświadczenia religijnego. Opisane przemiany sugerują odpowiednie modyfikacje w podejściach badawczych. 


\section{Literatura:}

Berger, P., Luckmann, T. (1983). Społeczne tworzenie rzeczywistości. Warszawa: PWN. Berger, P. (1990). Modernizacja jako uniwersalizacja herezji. W: H. Grzymała-Moszczyńska (red.), Religia a życie codzienne, cz. I (s. 13-46). Kraków: UJ.

Berger, P. (1998). Sekularyzm w odwrocie. Res Publica Nowa, 1 (112). s. 67-74.

Borowik, I. (1990). Charyzma a codzienność. Kraków: UJ.

Brach-Czaina, J. (1999). Szczeliny istnienia. Kraków: Wydawnictwo eFKa.

Caillois, R. (1995). Człowiek i sacrum. Warszawa: Oficyna Wydawnicza Volumen.

Calhoun, C., Juergensmeyer, M., VanAntwerpen, J. (red.), (2011). Rethinking secularism. New York: Oxford University Press.

Casanova, J. (2006). Rethinking Secularization: A Global Comparative Perspective. The Hedgehog Review. Critical Reflections on Contemporary Culture, 1-2 (8), s. 7-22.

Cicourel, A. (1984). Etnometodologia. W: E. Mokrzycki (red.), Kryzys i schizma. Antyscjentystyczne tendencje w socjologii współczesnej, t. 1 (s. 221-302). Warszawa: Państwowy Instytut Wydawniczy.

Cicourel, A. (1989). Założenia teoretyczne. W: Z. Krasnodębski (red.), Fenomenologia i socjologia (s. 378-425). Warszawa: PWN.

Coenen, H. (1989). Cielesność a życie społeczne. O podstawowym problemie socjologii fenomenologicznej. W: Z. Krasnodębski (red.), Fenomenologia i socjologia (s. 255-286). Warszawa: PWN.

Dilthey, W. (2004). Budowa świata historycznego w naukach humanistycznych. Gdańsk: Słowo/obraz terytoria.

Duranti, A. (2010). Husserl, intersubjectivity and anthropology. Anthropological Theory, 1 (10). Pobrane z: http://www.sscnet.ucla.edu/anthro/faculty/duranti/Husserl-Intersubject-AT.pdf.

Garfinkel, H. (1989). Aspekty problemu potocznej wiedzy o strukturach społecznych. W: Z. Krasnodębski (red.), Fenomenologia i socjologia (s. 324-342). Warszawa: PWN.

Gatskova, K. (2014). Can increasing religiosity foster democratization in Ukraine? Policy Issues, 3. Regensburg: Institut für Ost - und Südosteuropaforschung. Pobrane z: http:// www.dokumente.ios-regensburg.de/publikationen/policy_issue/policy_issue_3.pdf.

Geertz, C. (1992). Religia jako system kulturowy. W: E. Mokrzycki (red.), Racjonalność i styl myślenia (s. 498-555). Warszawa: IFiS PAN.

Geertz, C. (2005). Wiedza lokalna. Dalsze eseje z zakresu antropologii interpretatywnej. Kraków: Wydawnictwo UJ.

Golka, M. (2009). Czy jeszcze istnieje nie-codzienność? W: M. Bogunia-Borowska (red.), Barwy codzienności (s. 65-76). Warszawa: Scholar.

Grathoff, R. (1989). Codzienność i świat przeżywany jako przedmiot fenomenologicznej teorii społecznej. W: Z. Krasnodębski (red.), Fenomenologia i socjologia (s. 426-457). Warszawa: PWN.

Habermas, J. (2000). Filozoficzny dyskurs nowoczesności. Kraków: TAiWPN Universitas. Habermas, J. (2003). Teoria działania komunikacyjnego, t. 2. Warszawa: Wydawnictwo Naukowe PWN.

Hannerz, U. (2006). Skreolizowany świat. W: M. Kempny, E. Nowicka (red.), Badanie 
kultury. Elementy teorii antropologicznej. Kontynuacje (s. 284-298). Warszawa: Wydawnictwo Naukowe PWN.

Heidegger, M. (1994). Bycie i czas. Warszawa: Wydawnictwo Naukowe PWN.

Husserl, E. (1989). Nastawienie nauk przyrodniczych i humanistycznych. Naturalizm, dualizm i psychologia psychofizyczna. W: Z. Krasnodębski (red.), Fenomenologia i socjologia (s. 53-74). Warszawa: PWN.

Jackson, M. (2008). Existential Anthropology: Events, Exigencies and Effects. New York: Berghahn Books.

James, W. (1957). Pragmatyzm. Popularne wykłady z zakresu filozofii. Warszawa: Książka i Wiedza.

James, W. (1958). Doświadczenia religijne. Warszawa: Książka i Wiedza.

Krasnodębski, Z. (1991). Kryzys nowoczesności a świat przeżywany. W: A. Jawłowska (red.), Kategoria potoczności. Źródła filozoficzne i zastosowania teoretyczne (s. 39-66). Warszawa: IFiS PAN.

Lachowska, D. (1987). Codzienność i rozumienie w teorii Alfreda Schütza. W: Z. Krasnodębski (red.), Od transcendentalizmu ku hermeneutyce (s. 159-174). Warszawa: Wydawnictwo UW.

Lash, S. (2009). Refleksyjność i jej sobowtóry: struktura, estetyka, wspólnota. W: U. Beck, A. Giddens, S. Lash, Modernizacja refleksyjna. Polityka, tradycja i estetyka w porządku społecznym nowoczesności (s. 145-221). Warszawa: Wydawnictwo Naukowe PWN.

Luckmann, T. (1989). O granicach świata społecznego. W: Z. Krasnodębski (red.), Fenomenologia i socjologia (s. 287-323). Warszawa: PWN.

Luhmann, N. (1998). Funkcja religii. Kraków: Zakład Wydawniczy Nomos.

Machaj, I., Gołdyka, L. (red.) (2007). Enklawy życia społecznego. Szczecin: Wydawnictwo Naukowe US.

Machaj, I., Gołdyka, L. (red.) (2009). Enklawy życia społecznego. Kontynuacje. Szczecin: Wydawnictwo Naukowe US.

Mandes, S. (2012). Świat przeżywany w socjologii. Warszawa: Wydawnictwo UW.

Manterys, A. (1997). Wielość rzeczywistości w teoriach socjologicznych. Warszawa: Wydawnictwo Naukowe PWN.

Mariański, J. (2006). Sekularyzacja i desekularyzacja w nowoczesnym świecie. Lublin: KUL.

McGuire, M. (2008). Religion. The social context. Long Grove: Waveland Press.

Mokrzycki, E. (1992). Socjologia a filozofia: punkt widzenia socjologa. W: H. Kozakiewicz, E. Mokrzycki, M. Siemek (red.), Racjonalność współczesności. Między filozofią a socjologią (s. 247-251). Warszawa: Wydawnictwo Naukowe PWN.

Natanson, M. (1982). Introduction. W: M. Natanson, H. van Breda (eds.), A. Schütz, Collected Papers 1. The Problem of Social Reality (s. xxv-xLvi). The Hague: Springer.

Patočka, J. (1987). Świat naturalny i fenomenologia: teksty filozoficzne. Kraków: Papieska Akademia Teologiczna.

Piwowarski, W. (1974). Socjologiczna definicja religii. Studia Socjologiczne, 2 (53). s. $197-218$.

Rolewski, J. (1999). Rozum, nauka, świat przeżywany. Studium filozofii „późnego” Husserla. Toruń: Wydawnictwo UMK. 
Schelsky, H. (1998). Czy trwała refleksja podlega instytucjonalizacji? W: W. Piwowarski (red.), Socjologia religii. Antologia tekstów (s. 189-206). Kraków: Zakład Wydawniczy Nomos.

Schütz, A., Luckmann, T. (1973). The Structures of the Life-World, vol. 1. Evanston: Northwestern University Press.

Schütz, A., M. Natanson, H. van Breda (red.), (1982). Collected Papers 1. The Problem of Social Reality. The Hague: Springer.

Schütz, A., Wagner, H. (red.), (1999). Alfred Schutz on Phenomenology and Social Relations. Chicago: University of Chicago Press.

Sztompka, P., Bogunia-Borowska, M. (red.), (2008). Socjologia codzienności. Kraków: Wydawnictwo Znak.

Taylor, C. (2007). A Secular Age. Cambridge, Ma: Harvard University Press.

Tischner, J. (1993). Myślenie według wartości. Kraków: Wydawnictwo Znak.

Waldenfels, B. (1989). Rozumienie i porozumienie. Filozofia społeczna Alfreda Schütza. W: Z. Krasnodębski (red.), Fenomenologia i socjologia (s. 235-254). Warszawa: PWN.

Węgrzecki, A. (1996). Zarys fenomenologii podmiotu. Wrocław, Warszawa, Kraków: Zakład Narodowy im. Ossolińskich.

Wittgenstein, L. (1995). Uwagi o religii i etyce. Kraków: Wydawnictwo Znak.

Zimmerman, D., Pollner, M. (1989). Świat codzienny jako zjawisko. W: Z. Krasnodębski (red.), Fenomenologia i socjologia (s. 343-377). Warszawa: PWN. 